Article

\title{
Changes in the Influence of Social Responsibility Activities on Corporate Value over 10 Years in China
}

\author{
Feifei Zhang and Jin-young Jung *(1) \\ College of Business Administration, Inha University, Incheon 22212, Korea; zhangfeifei2020@inha.edu \\ * Correspondence: jyjung@inha.ac.kr
}

Received: 15 September 2020; Accepted: 11 November 2020; Published: 15 November 2020

\begin{abstract}
This study analyzes changes in how corporate social responsibility (CSR) affects corporate value in China. We use multiple regression analysis on a sample of A-share listed companies on the Shanghai and Shenzhen Stock Exchanges from 2009 to 2018. We divide the sample into 2009-2012 and 2013-2018 periods according to the development of CSR-related media and corporate policies. The dependent variable is corporate value, measured by Tobin's $Q$. The independent variable is the CSR score calculated and published by RKS, a widely recognized CSR evaluation agency in China. We use firm size, sales growth rate, return on equity, top 10 shareholders' equity, operating cash flow, and debt ratio as control variables. The panel-based regression models find no statistical correlation between CSR score and corporate value from 2009 to 2012 but find that the CSR score has a significantly positive influence on corporate value from 2013 to 2018. The impact of CSR activities on corporate value increases over the 10-year period. This decade saw the Chinese government shift its development strategy from a rapid growth model to a high-quality growth model and pursue sustainable development. This study is useful for Chinese companies considering adopting CSR activities to promote sustainable development.
\end{abstract}

Keywords: China; corporate social responsibility; corporate value; CSR; sustainability; Tobin's Q

\section{Introduction}

China's economy has been in a high-growth stage since the country's reform and opening-up began in 1978. During this stage, the primary objective was rapid growth in the economy. China's average growth rate has been $9.3 \%$ over this period. However, this economic growth has come at a heavy price. This price has come in two main forms: environmental destruction and a serious gap between the rich and poor. To solve these problems, the Chinese government has shifted its development strategy from a rapid growth model to a high-quality growth model and has pursued sustainable development.

Corporate social responsibility (CSR), as a prerequisite for achieving sustainable development and management, is getting more and more attention. CSR activities can make a major contribution to sustainable development [1] for several reasons. First, companies protect the environment when they engage in CSR activities, which forms the material basis for corporate sustainable development. Second, CSR activities enable companies to improve their management environment and sustainable management capacity by reducing friction between stakeholders. Third, a company can establish a good image by conducting CSR activities, which can accelerate its development.

The traditional corporate perception of CSR activities in China has tended to be passive. According to this view, CSR activities consume company resources and lower its economic power; it may improve corporate value in the long term, but it decreases it in the short term. In this perception, CSR activity is more about showing charity than doing it. However, in today's Internet age, the real CSR activity is the conduct of business itself. For example, Chinese delivery company MEITUAN reported on its CSR activities in 2018 by claiming that its drivers had delivered food to nearly 20 million elderly 
people who were unable to cook and made more than 14 million deliveries to white collar workers after 8 p.m. The report claims that this helped the company provide 19.6 million job opportunities and that 670,000 drivers out of 2.7 million job opportunities come from 781 poverty-stricken prefectures. Add to the Internet allows information to be transmitted anywhere in the world in seconds the public is able to obtain information on firms' CSR activities immediately. Sensitive investors can use this information to predict whether a company will do well and thus whether to invest. Therefore, more and more corporations have begun to attach importance to CSR activities and believe that conducting CSR activities can improve their corporate values and certainly help them to realize their long-term development.

This research is different from most of the previous studies that focused on the relationship between CSR and corporate value; we focused on the change of the relationship between them. This study is based on the sample of 111 listed Chinese companies for the period from 2009 to 2018. We find that the relationship between CSR and corporate value has changed from no relationship in 2009-2012 to a positive relationship in 2013-2018. The correlation between them has also become stronger.

This study contributes to the literature in several ways. First, most of the studies that have examined the relationship between CSR and corporate value have investigated whether the relationship is positive [2-34], negative [35-43], or there is no relationship [44-47] or have explored how CSR activities affect corporate value in the short or long term [48-52]. No study has examined how the relationship between CSR activities and corporate value changes in a rapidly changing economic environment. This study focuses on the changes in the impact of CSR activities on corporate value. Second, most of the research on the relationship between CSR activities and corporate value uses a maximum of three years of data [26,53,54], but this study's sample period spans 2009 to 2018, providing 10 years of data. This expanded sample size allows us to analyze recent trends in the impact of CSR activities on corporate value.

The rest of the paper is organized as follows. In the next section, we review the literature. Section 3 develops our research hypotheses. Section 4 explains the study's methodology. Section 5 presents the results. Finally, Section 6 concludes the paper.

\section{Literature Review}

\subsection{The Development of CSR Theory}

Corporate social responsibility requires companies to pursue profits and fulfil their legal responsibilities to shareholders and employees, as well as to consumers, society, and the environment. To do this, companies must go beyond the traditional ideology whereby profit is the only goal and emphasize human values in the production process and contribute to the welfare of the environment, consumers and society.

In Stage 1, the concept of CSR was established. British scholar Oliver Sheldon [55] first proposed the concept of CSR in 1923. He believed that CSR is more focused on ethics. In 1953, American scholar Howard Bowen [56] published Social Responsibility of the Businessman which examines the responsibilities businesspeople have to society. Bowen argues that businesses should consider social goals and values when setting policies and to guide their conduct. As this claim provides the first definition of CSR, Bowen is said to be the "father" of CSR.

In Stage 2, CSR theory was developed, and CSR activities gradually became popular in developed countries such as the United States and in Europe. In 1979, Archie Carroll [57] presented the theory of the "Pyramid of Corporate Social Responsibility." Carroll argued that CSR comprises a firm's economic, legal, ethical, and philanthropic expectations. The Pyramid of Corporate Social Responsibility has become the most widely used CSR theory. John Elkingtor proposed the "triple bottom line" theory in 1997. He believed that corporate social responsibility can be divided into economic responsibility, environmental responsibility, and social responsibility [58]. 
In Stage 3, CSR gained worldwide attention. In 2000, the American Commercial Social Responsibility Association announced that CSR is about respecting ethical values, legal requirements, people, local communities, and the environment when determining company policies. The Commission of the European Union (EU) announced in 2001 that CSR should always be voluntary and that a company's interest in society and the environment should be combined with its management and interactions with stakeholders. In 2010, 77 countries adopted the Guidance on Social Responsibility (ISO 26000); this provides a clear definition of social responsibility, describing it as a company's assumption of responsibility for the impact of its actions on society and the environment through transparency and moral conduct.

\subsection{CSR in China}

Since China's reform and opening in 1978, China has gone from being a planned economy to being a planned commodity economy, and finally a socialist economic system with Chinese characteristics. Corporate social responsibility emerged in China during the reform/opening-up period and has developed in unique ways over the past 40 years. This development can be divided into three stages.

Stage 1 occurred from 1978 to 2008. When China began its reform and opening-up, Deng Xiaoping's famous "black and white cat" theory (a good cat, whether white or black, catches mice) encouraged people to produce as much as possible, but it also created many social problems. The quantity of products greatly increased, but fake, low-quality goods became rampant due to product quality issues. Against this background, the legal system quickly addressed problems in areas such as consumer rights protection, workers' rights protection, and environmental protection. In this context, corporate management philosophies, corporate social values, and corporate and social relations became matters of increasing interest, which enhanced the profile of CSR among Chinese companies.

In 2003, the $\mathrm{Hu}$ Jintao-Wen Jiabao government established the scientific development perspective [22]. The first essence of the scientific development concept is economic development, the core is people-oriented, and the fundamental method is overall planning. In 2006, the government put forward the idea of building a harmonious society; such a society features democratic rule of law, fairness and justice, honesty and friendship, an energetic atmosphere, well-organized practices, and a harmonious coexistence between humans and nature. China's CSR has developed rapidly in accordance with the scientific development view and the "harmonious society" policy. Corporate social responsibility has appeared on China's national horizon, and Chinese leaders have endorsed CSR on several occasions.

The first year of CSR in China is said to be 2008, when a number of symbolic events occurred that promoted the development of Chinese CSR activities and ideology among the public [59]. In January 2008, the SASAC issued the Guidelines for Central Enterprises to Fulfill Social Responsibilities, which is considered a CSR milestone in China. In May 2008, the Shanghai Stock Exchange published the Notice on Strengthening the Social Responsibility Work of Listed Companies and the Guidelines on the Environmental Information Disclosure of Listed Companies. These all promoted the development of CSR in China. Moreover, several major events also helped promote CSR in 2008, such as the winter snowstorms, the Sichuan earthquake, and the Sanlu milk powder incident. First, starting on 3 January 2008, 20 provinces-including Shanghai, Jiangsu, and Henan-suffered from low temperatures, heavy snow, and ice to different degrees. In the face of the resulting disasters, various sectors of society participated in rescue efforts. Second, on 12 May 2008, a large earthquake occurred in Sichuan Province, leading to many geological disasters such as massive landslides, collapses, and debris flow. The damaged area totaled $100,000 \mathrm{~km}$. Tens of thousands of people voluntarily went to the disaster area to assist in rescue missions, and many companies participated in relief efforts. Finally, on 11 September 2008, about 700 tons of baby formula made by Sanlu were found to contain melamine. About 290,000 infants in China developed urinary abnormalities due to milk powder containing melamine, more than 10,000 infants were treated in hospital, and six infants died. In a heartbreaking development, on 16 September, China's quality supervision agency announced the 
results of a test that extracted milk powder from more than 100 milk powder companies across the country: Melamine was detected in the milk powder of 22 companies, most of them famous in China. This case undermined public confidence in China's companies, and the public strongly condemned irresponsible corporate conduct.

Stage 2 occurred from 2009 to 2012. Due to the many cases of corporate irresponsibility that occurred in 2008, the Shanghai and Shenzhen securities exchanges required listed companies to disclose CSR information starting in December of that year. Thus, Chinese CSR underwent a period of rapid development from 2009 to 2012. During this period, all of Chinese society participated in CSR activities. Companies recognized the importance and necessity of social responsibility and carried out CSR activities accordingly. In 2009, the Chinese Academy of Social Sciences published China's Top 100 Social Responsibility Development Index (2009). As a result of this development, 290 companies released social responsibility reports in 2008, 371 did so in 2009, and 471 did so in 2010 . The number of public companies releasing social responsibility reports is increasing significantly.

Stage 3 occurred from 2013 to 2018. During this stage, Chinese CSR was characterized by standardization, normalization, internationalization, and high-level attention. The Xi Jinping government, which began at the end of 2012, put increased CSR pressure on companies with the goal of eliminating poverty, narrowing the gap between rich and poor, solving environmental problems, eliminating corruption, and ensuring food safety as the top priorities. Xi Jinping argued in his book [60] that loving property is the only truly meaningful property and that companies that pursue CSR are the most competitive and vital. On 1 January 2015, the Environmental Protection Act was officially implemented. The act increases penalties for environmental pollution, and even forces companies that fail to protect the environment to stop production.

On 2 June 2015, the General Administration of Quality Supervision (AQSIQ) and the Standardization Administration of China jointly announced a series of social responsibility national standards. These include the Guidelines for Social Responsibility, the Guide to the Preparation of Social Responsibility Reports, and the Social Responsibility Performance Classification Guide. This series is China's first national standard document in the field of social responsibility. The presentation of this series helped raise the level of social responsibility in China. As the global division of labor continues to deepen and the supply chain continues to expand, the sense of social responsibility and supply chain partnerships in corporate management are important factors affecting firm competitiveness. Interest in corporate and social responsibility is increasing across all sectors of Chinese society, and Chinese governments at all levels have released guidance documents on social responsibility. About 40 social responsibility standards have been established by 20 commercial associations. Many universities have established professional CSR research standards. In addition, many media organizations have pursued activities such as holding social responsibility forums to promote the spread of the CSR ideology throughout society.

\subsection{Research on Relationship between CSR and Corporate Value}

The empirical research on the correlation between corporate value and social responsibility activities has offered three perspectives on the issue: They have found a positive correlation, negative correlation, and no correlation between corporate value and CSR.

A negative correlation between CSR and corporate value is found if a company's CSR activities are observed to degrade its value. Friedman [36] argued that the only responsibility of the corporation is to increase a company's profits by making full use of its resources in an environment of open and free competition. From the shareholders' perspective, the expenditures required to engage in social responsibility activities is seen as a waste of company resources, which causes agency problems. According to Aupperle et al. [37], CSR activities waste capital and other resources, and companies that engage in them cannot compete against those that do not. In the empirical study of Vance [35], CSR activities are found to have negative effects on corporate value. 
On the other hand, Ullman [46] found no correlation between CSR activities and corporate value and argued that it is difficult to think of a reason why they would be correlated. Bauer et al. (2005) [47] showed that there is no significant difference in performance between CSR active companies and control group companies.

However, many studies have shown that CSR activities have a positive effect on corporate value and corporate financial performance. In this case, companies can increase their corporate value through CSR activities. According to the stakeholder approach proposed by Freeman [9] that CSR activities satisfy the interests of all of a firm's stakeholders can increase company profits in the long run. Frank (2018) [7] collected data of South African listed companies and found a positive and statistically significant relationship between social disclosure performance and firm value. Elif Akben-Seluck (2019) [3] used the listed company in Turkey as the sample shows that corporate social responsibility has a positive relationship with financial performance. Ju Hyoung Park (2018) [2] found that, on average, firms can increase their value through CSR activities in Korea.

Among the studies that examine the correlation between CSR and corporate value for Chinese companies, Li (2006) [38] investigated 521 companies listed on the Shanghai Stock Exchange in 2003 and found that CSR activities have a negative effect on corporate value in the current period but have a positive effect in the long run. Pan and Wang (2015) [44] studied the relationship between environmental protection investment and financial performance, finding no correlation in the short term (within one year) and a positive relationship in the long term (two years). Kong and Li (2010) [14] used stakeholder theory and found a positive relationship between social responsibility indicators and financial performance. In addition, Yang (2014) [15] shows that the companies listed on the Shanghai and Shenzhen Securities Exchange A markets display a positive correlation between CSR and financial performance through multiple regression analysis. Seo and Park (2015) [22] found that CSR had a positive effect on corporate value for companies listed on the Shanghai and Shenzhen Securities Exchange A markets from 2009 to 2013. Jin, Yang, Hong, and Choi [26] found that both Korean and Chinese companies show positive relationships between CSR activities and corporate value for both the next year $(t+1)$ and the next two years $(t+2)$.

\section{Hypotheses}

This study tests how the impact of CSR on corporate values changes in China between 2009 and 2018. We first divide the study period into two stages, 2009-2012 and 2013-2018, according to three dimensions: the development of government CSR-related policies, media issues, and corporate issues.

\subsection{Government and Related Policy Dimension}

The Xi Jinping government, in power since the end of 2012, has put forward the concept of building a moderately prosperous society in all respects and building a modern socialist country that is prosperous, strong, democratic, culturally advanced, and harmonious to realize the Chinese dream of the great rejuvenation of the Chinese nation. This is different from the scientific development concept proposed by the $\mathrm{Hu}$ Jintao government, in which development was the priority. Before 2013, the government's policy on corporate CSR activities was mainly to guide and advise. Since 2013, however, CSR activities have been applied to national strategies, and laws and regulations governing CSR activities have been increasing, while local governments have also issued guidance documents and implementation systems for CSR.

\subsection{Media Dimension}

Chinese mass media such as the People's Daily Online and Xinhua have promoted the spread of CSR in society by holding CSR forums, giving out CSR awards, and reporting on outstanding CSR practices. Meanwhile, the popularity of smartphones has produced the era of mobile Internet. As Figure 1 shows, the number of mobile netizens has been increasing since 2008, exceeding 500 million in 2013 and exceeding 800 million in 2018. The share of mobile netizens in the netizen population increased rapidly 
from $39.5 \%$ in 2008 to $80 \%$ in 2013 , and then rose steadily to $98.6 \%$ by 2018 . Figure 2 shows that the number of WeChat users has been rapidly increasing since it launched in January 2011. It has become the most widely used messenger platform in China. In this environment, new ways of spreading news, called "we-media," have emerged. The official WeChat account was developed in 2013 and is now the most-used we-media in China. Media platforms, companies, and individuals can all publish articles through WeChat's official accounts, and the Chinese have become used to watching news through WeChat. Such advances in technology have greatly promoted the spread of CSR among the Chinese public.

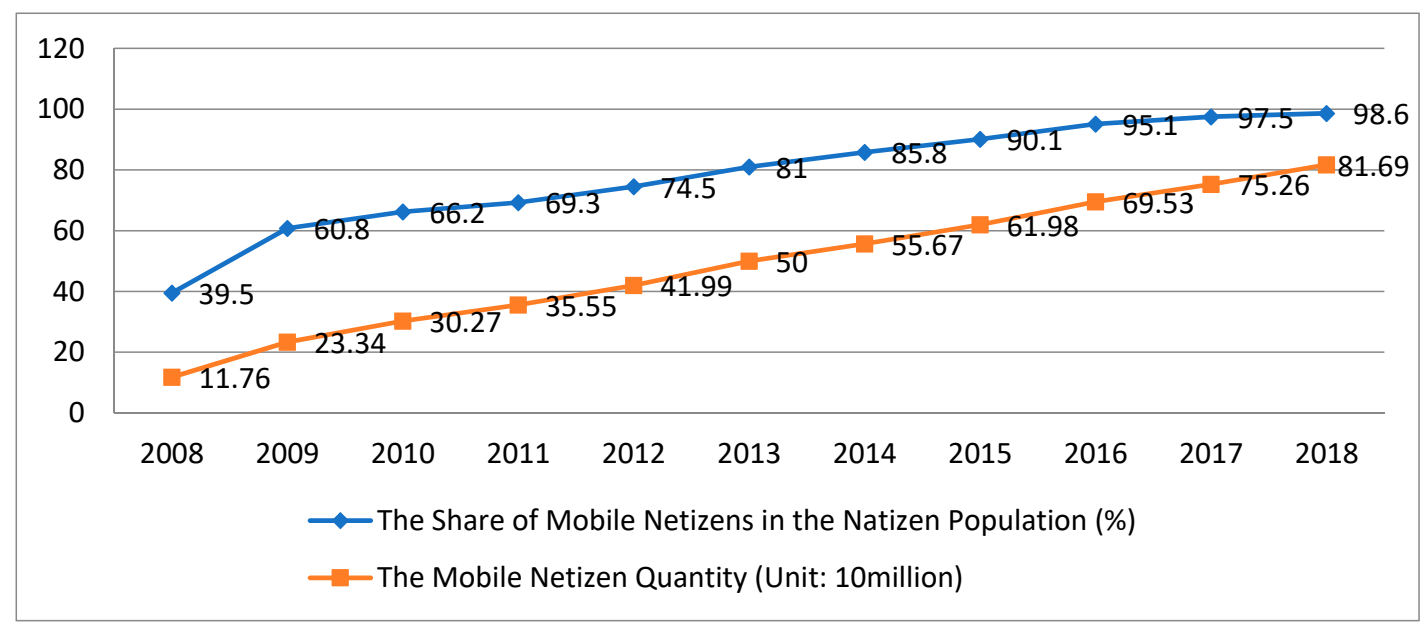

Figure 1. Mobile netizen quantity and share of mobile netizens in the netizen population.

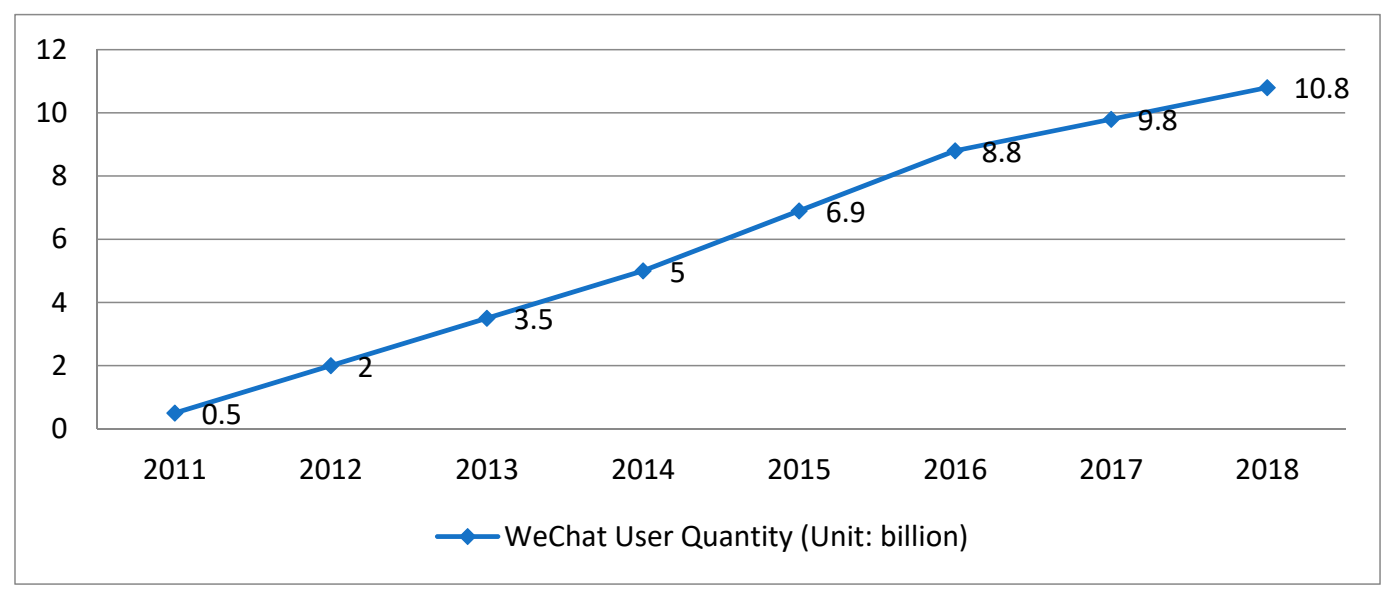

Figure 2. WeChat user quantity.

\subsection{Corporate Dimension}

As CSR has developed in China, companies have changed their attitudes toward it considerably and have recognized its importance to their performance. Whereas companies initially believed that CSR activities only increased their costs, companies are increasingly realizing that CSR is not only good for society but also plays an important role in their own development. An increasing number of companies are actively engaging in CSR activities, and many companies' CSR activities have penetrated through the firms' production management processes in an effort to promote sustainable development. As Figure 3 shows, the number of A-share companies reporting CSR via the Shanghai and Shenzhen Stock Exchanges increased between 2009 and 2018, exceeding 600 by 2013 and growing stably since then. 


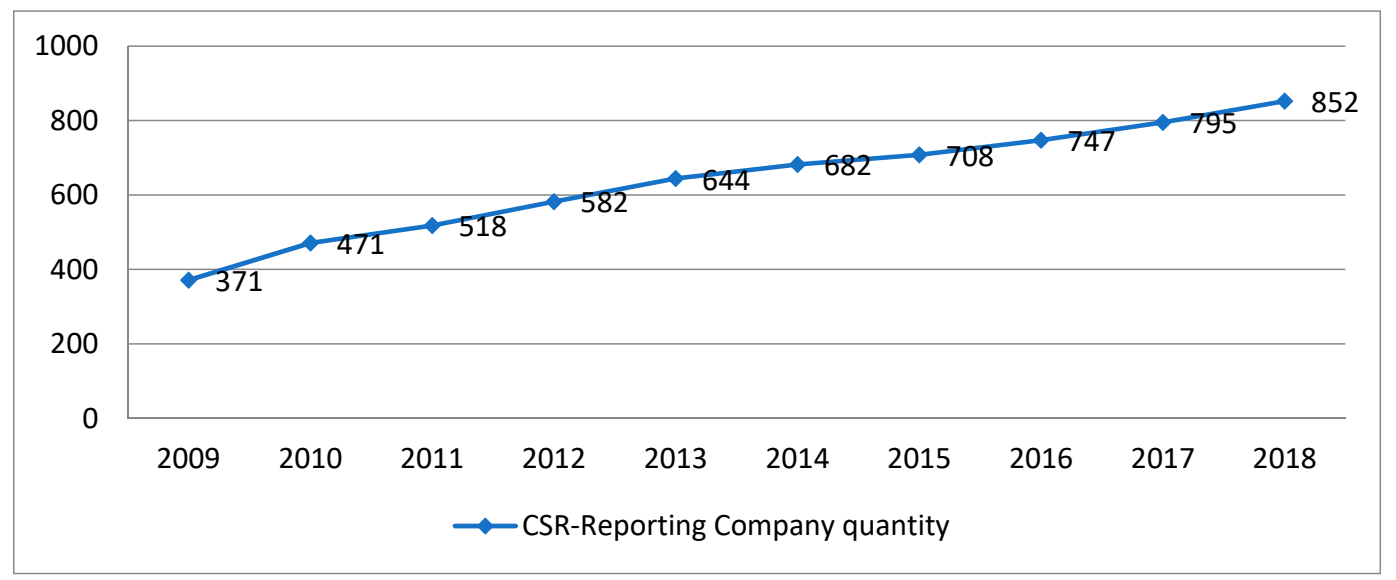

Figure 3. Corporate social responsibility (CSR)-reporting company quantity.

In the 2009-2012 period, the Chinese state was unclear about the proper CSR assessment standards, policies, and laws. The media were giving CSR little publicity, and companies were also unsure about CSR activities. In addition, prior studies suggest that CSR and corporate value have a mostly negative correlation or no correlations in this early period. Therefore, based on the above discussion, we propose the following:

Hypothesis 1. From 2009 to 2012, CSR activities had a negative impact on corporate value for Chinese companies.

The 18th National Congress of the Communist Party of China was held in November 2012, and a new government was elected. China entered a period of comprehensively deepening reforms. After 2013, the new government has emphasized CSR at the national strategy level, launched a number of policies related to CSR, and issued national CSR standards, while laws related to CSR have become stronger. The «Decision of the CPC Central Committee on several Major Issues concerning comprehensively deepening the Reform» adopted at the Third Plenary Session of the 18th CPC Central Committee held in 2013 for the first time promoted social responsibility work as a key task in the reform of state-owned enterprises. In 2014, the Fourth Plenary Session of the 18th CPC Central Committee adopted the «Decision of the CPC Central Committee on Several Major Issues concerning comprehensively advancing the rule of law», which clearly proposed to strengthen the legislation of corporate social responsibility as one of the tasks of strengthening legislation in key areas. In 2015 GB/T 36000-2015 «Guidelines for Social Responsibility», GB/T 36001-2015 «Guidelines for the compilation of social responsibility reports», GB/T 36002-2015 «Guidelines for the classification of social responsibility performance» three national standards were officially released. In addition, advances in science and technology enabled the media to quickly and accurately deliver CSR-related information to the public. The importance of CSR was disseminated to the public, whose interest in CSR increased. Companies also recognized the importance of CSR and actively participated in CSR activities. Moreover, the most recent studies show that CSR had a positive effect on corporate value. Therefore, we propose the following:

Hypothesis 2. From 2013 to 2018, CSR activities had a positive impact on corporate value for Chinese companies.

A 2018 case of vaccine manipulation led to widespread reflection in Chinese society. On 15 July 2018, an announcement from the State Drug Administration (SDA) reveals the inside story behind the manipulation of the Changchun Changsheng Biological Company. The 252,600 vaccines produced by the company had already been distributed to each province, 247,359 people had already been inoculated, 215,184 of them children. As soon as the manipulation took place, the WeChat Official Account reported on it, which aroused public anger. Premier Li Keqiang claimed that the vaccine 
case had crossed a moral line, that the nation deserved a clear explanation that the State Council would immediately send a group to thoroughly investigate the production and selling chain of the vaccine to uncover the truth as soon as possible, and that any wrongdoing would be severely punished regardless of who is involved. The case was later thoroughly investigated, and the company and its managers were severely punished. The company went bankrupt. However, in March 2009, Yanshen Company was similarly found to have manipulated vaccines. In this case, 180,000 vaccines had already been distributed to 21 provinces and had been used on humans. In this case, there was no recall or compensation, a fine of only 3 million yuan was imposed on the company and the general manager, and only five employees were found criminally guilty. Jiangsu Yanshen quickly makes a comeback. Just six months later, the firm received 1.6 million orders from the epidemic prevention department worth more than 100 million yuan. It was soon licensed to make swine flu vaccines. These two events are very similar, but the consequences for the two companies varied considerably depending on the timing of the events. Therefore, this study argues that social responsibility has a greater impact on corporate value over time. We thus propose the following:

Hypothesis 3. The impact of CSR activities on corporate value in China was greater from 2013 to 2018 than it was from 2009 to 2012.

\section{Methodology}

\subsection{Data: Sample Selection and Sources}

The sample used in this study comprises all Chinese companies listed on the Shanghai and Shenzhen Stock Exchanges' A markets between 2009 and 2018 that

1. have financial information in China Stock Market \& Accounting Research Database (CSMAR),

2. have a settlement date of 31 December,

3. have CSR activity scores in RKS (Rankins CSR Ratings),

4. are non-financial companies.

The CSMAR economic and financial research database draws on the research and precision database specifically developed for the Chinese financial and economic fields, drawing on internationally renowned economic and financial database standards such as CRSP and Standard \& Poor's Compustat from the University of Chicago. The data come from the Shanghai Stock Exchange, Shenzhen Stock Exchange, Shanghai Commodity Futures Exchange, Zhengzhou Commodity Futures Exchange, Dalian Commodity Futures Exchange, and other authoritative publishing agencies. These data are accurate, wide-ranging, complete in time, and abundant in indicators, and are therefore appropriate for the purposes of this study [26,61].

The CSR score provided by RKS is used as the company's CSR score in this study [22,26]. RKS was established in 2007 and is an authoritative third-party institution that evaluates Chinese corporate social responsibility. The study considers only companies with a settlement date of 31 December because different settlement dates may have different effects on firms' financial information depending on their economic environment. Moreover, financial companies have different financial statements, and the same indicators can have different meanings across firms. Thus, these firms are excluded from the sample.

As this study examines how the impact of CSR scores on corporate value changes during the sample period, the sample needs to be comparable over time. We select 111 companies according to the process shown in Table 1 below. 
Table 1. Sample selection process.

\begin{tabular}{|c|c|c|c|c|c|c|c|c|c|c|}
\hline & 2009 & 2010 & 2011 & 2012 & 2013 & 2014 & 2015 & 2016 & 2017 & 2018 \\
\hline Listed companies with December settlement & 1774 & 2215 & 2450 & 2578 & 2622 & 2737 & 2925 & 3219 & 3596 & 3690 \\
\hline Companies without CSR scores & 1459 & 1743 & 1931 & 1995 & 1968 & 2055 & 2217 & 2471 & 2773 & 2833 \\
\hline Companies with CSR scores & 315 & 472 & 519 & 583 & 654 & 682 & 708 & 748 & 823 & 857 \\
\hline Financial companies & 15 & 15 & 15 & 15 & 15 & 15 & 15 & 15 & 15 & 15 \\
\hline Final sample & 111 & 111 & 111 & 111 & 111 & 111 & 111 & 111 & 111 & 111 \\
\hline
\end{tabular}

\subsection{Model}

We tested the changes in the impact of Chinese CSR activities on corporate value over 10 years by estimating Equations (1) and (2):

TQ09-12 $=\beta 0+\beta 1$ CSR09-12 + $\beta 2$ SIZE09-12 + $\beta 3$ SGR09-12 + $\beta$ 4ROE09-12 + $\beta 5$ OWN09-12 +

$$
\beta 6 \text { OCF09-12 + } \beta \text { LLEV09-12 + } 209-12
$$

where TQ09-12 = AVG (2009 TQ-2012 TQ), TQ = (market value of equity + book value of debt)/book value of total assets,

CSR09-12 = AVG (2009 CSR-2012 CSR), CSR = CSR total presented by RKS,

SIZE09-12 = AVG (2009 SIZE-2012 SIZE), SIZE = ln (Ending total assets),

SGR09-12 = AVG (2009 SGR-2012 SGR), SGR = (Current sales - Pre-sales)/Pre-sales,

ROE09-12 = AVG (2009 ROE-2012 ROE), ROE = Net income/Stockholder's equity,

OWN09-12 = AVG (2009 OWN-2012 OWN), OWN = Top 10 Shareholders' Equity Rate,

OCF09-12 = AVG (2009 OCF-2012 OCF), OCF = Operating cash flow/Beginning total assets,

LEV09-12 = AVG (2009 LEV-2012 LEV), LEV = Total debt/Total assets,

$\varepsilon 09-12$ = error term.

TQ13-18 $=\beta 0+\beta 1$ CSR13-18 + $\beta 2$ SIZE13-18 + $\beta 3$ SGR13-18 + $\beta$ 4ROE13-18 +

$$
\beta 5 \mathrm{OWN13}-18+\beta 6 \mathrm{OCF} 13-18+\beta 7 \mathrm{LEV} 13-18+\varepsilon 13-18
$$

where TQ13-18 = AVG (2013 TQ 2018 TQ), TQ = (market value of equity + book value of debt)/book value of total assets,

CSR13-18 = AVG (2013 CSR-2018 CSR), CSR = CSR total presented by RKS,

SIZE13-18 = AVG (2013 SIZE-2018 SIZE), SIZE = ln (Ending total assets),

SGR13-18 = AVG (2013 SGR-2018 SGR), SGR = (Current sales - Pre-sales)/Pre-sales,

ROE13-18 = AVG (2013 ROE-2018 ROE), ROE = Net income/Stockholder's equity,

OWN13-18 = AVG (2013 OWN-2018 OWN), OWN = Top 10 Shareholders' Equity Rate,

OCF13-18 = AVG (2013 OCF-2018 OCF), OCF = Operating cash flow/Beginning total assets,

LEV13-18 = AVG (2013 LEV-2018 LEV), LEV = Total debt/Total assets,

$\varepsilon 13-18=$ error term.

The values of the variables used in Equation (1) are the average values of each variable from 2009 to 2012, and the values of the variables used in Equation (2) are the average values of each variable from 2013 to 2018.

Tobin's $Q$ is the dependent variable of this study. Commonly used proxy variables of corporate value include market value, market/book ratio, price-to-earnings ratio, Return on Assets, and Tobin's Q. As the latter is the most commonly used in the literature $[22,23,26]$, we also adopt it for our analysis. Tobin's $Q$ is the ratio between the market value of the company asset and the total replacement cost of the asset. The total cost of replacement here refers to the cost of repurchasing the retained tangible asset. The higher the value of Tobin's $Q$, the higher the value of the company on the market.

We use CSR as the independent variable. The CSR scores are calculated and published by RKS; the highest possible score is 100 points. The annual CSR scores for the sample are shown in Table 2. 
As the table shows, the CSR scores' minimum, maximum, and average values all have upward trends over time.

Table 2. Sample's annual CSR scores.

\begin{tabular}{lcccc}
\hline & Minimum & Maximum & Mean & Std. Deviation \\
\hline CSR2009 & 15.20 & 68.76 & 29.693 & 10.195 \\
CSR2010 & 15.40 & 78.49 & 33.876 & 13.400 \\
CSR2011 & 16.12 & 79.54 & 35.789 & 15.047 \\
CSR2012 & 16.697 & 81.880 & 37.681 & 15.141 \\
CSR2013 & 18.479 & 81.702 & 39.680 & 14.459 \\
CSR2014 & 19.702 & 87.948 & 41.470 & 14.998 \\
CSR2015 & 28.964 & 89.298 & 44.416 & 13.740 \\
CSR2016 & 27.414 & 86.637 & 46.765 & 12.183 \\
CSR2017 & 33.002 & 86.550 & 47.843 & 12.167 \\
CSR2018 & 31.690 & 89.003 & 48.618 & 14.022 \\
\hline
\end{tabular}

Company size (SIZE), sales growth rate (SGR), return on equity (ROE), top 10 shareholders' equity (OWN), operating cash flows (OCF), and the debt-to-equity ratio (LEV) are used as control variables. We consider that a larger company size implies higher firm value due to economies of scale [34]. Theoretically, the higher the value of SGR, OCF, and ROE, the higher the value of the company (i.e., they are positively related to the value of the company). If $\mathrm{OWN}$ is high, the probability of major shareholders having an information asymmetry problem is high, as the major shareholders are likely to seek their own profits rather than those of the company [33]. We thus conjecture that OWN has a negative relationship with company value. Moreover, the higher the LEV, the lower the company's ability to repay debt; thus, a negative relationship with company value is expected.

\section{Results}

\subsection{Descriptive Statistics}

Tables 3 and 4 below provide the descriptive statistics of the average values of the main variables for 2009-2012 and 2013-2018 used in the regression model. For 2009-2012, the company's TQ values are distributed between 0.794 and 6.576, with an average value of 1728. However, in 2013-2018, the company's TQ minimum values increase slightly to 0.811 , but the maximum is 6271 , and the average value decreases slightly to 1610 . The CSR scores' minimum value, maximum value, and the average value for 2013-2018 are all higher than the values for 2009-2012. The standard deviation of the two periods is almost unchanged. While SIZE is higher from 2013 to 2018, SGR, ROE, OWN, OCF, and LEV are higher for 2009-2012.

Table 3. Descriptive statistics for 2009-2012.

\begin{tabular}{ccccccc}
\hline Variable & Obs. & Minimum & Maximum & Mean & Std. Deviation & Variance \\
\hline T Q 09-12 & 111 & 0.794 & 6.576 & 1.728 & 0.877 & 0.769 \\
CSR 09-12 & 111 & 17.268 & 76.395 & 34.260 & 12.723 & 161.879 \\
SIZE 09-12 & 111 & 20.313 & 26.851 & 23.133 & 1.454 & 2.113 \\
SGR 09-12 & 111 & -0.618 & 21.118 & 0.483 & 2.143 & 4.593 \\
ROE 09-12 & 111 & -0.092 & 0.267 & 0.105 & 0.071 & 0.005 \\
OWN 09-12 & 111 & 10.148 & 75.123 & 40.846 & 15.420 & 237.782 \\
OCF 09-12 & 111 & -0.024 & 0.216 & 0.064 & 0.051 & 0.003 \\
LEV 09-12 & 111 & 0.092 & 0.850 & 0.523 & 0.178 & 0.032 \\
\hline
\end{tabular}

Table 4. Descriptive statistics for 2013-2018.

\begin{tabular}{ccccccc}
\hline Variable & Obs. & Minimum & Maximum & Mean & Std. Deviation & Variance \\
\hline TQ 13-18 & 111 & 0.811 & 6.271 & 1.610 & 0.859 & 0.738 \\
CSR 13-18 & 111 & 30.560 & 85.910 & 44.799 & 12.766 & 162.974 \\
SIZE 13-18 & 111 & 20.473 & 27.379 & 23.669 & 1.489 & 2.217 \\
SGR 13-18 & 111 & -0.703 & 4.550 & 0.270 & 0.576 & 0.332 \\
ROE 13-18 & 111 & -0.547 & 0.289 & 0.063 & 0.113 & 0.013 \\
OWN 13-18 & 111 & 8.093 & 73.280 & 39.188 & 14.747 & 217.474 \\
OCF 13-18 & 111 & -0.041 & 0.233 & 0.058 & 0.050 & 0.003 \\
LEV 13-18 & 111 & 0.097 & 0.869 & 0.518 & 0.186 & 0.035 \\
\hline
\end{tabular}




\subsection{Correlation Analysis}

Table 5 shows the correlation between the average values of the main variables for 2009-2012. There is a significantly negative relationship between the CSR scores and corporate value (TQ), as expected. Carrying out CSR activities requires the company to spend large amounts of money and reduces its value in the short term. Looking at the correlation between corporate value (TQ) and other variables, company size (SIZE) surprisingly shows a negative relationship with corporate value (TQ). Return on equity (ROE) and operating cash flows (OCF) show positive relationships while debt-to-equity ratio (LEV) shows a negative relationship with corporate value (TQ), as predicted. Lastly, the sales growth rate (SGR) and the top 10 shareholders' equity (OWN) seem to have no statistical correlation with corporate value (TQ).

Table 5. Pearson correlation for 2009-2012.

\begin{tabular}{|c|c|c|c|c|c|c|c|c|c|}
\hline & (1) & (2) & (3) & (4) & (5) & (6) & (7) & (8) & VIF \\
\hline $\begin{array}{l}\text { (1) TQ } \\
09-12\end{array}$ & 1 & & & & & & & & - \\
\hline $\begin{array}{c}\text { (2) CSR } \\
09-12\end{array}$ & $-0.228^{* *}$ & 1 & & & & & & & 1.77 \\
\hline $\begin{array}{l}\text { (3) SIZE } \\
09-12\end{array}$ & $-0.417^{* * *}$ & $0.611^{* * *}$ & 1 & & & & & & 2.72 \\
\hline $\begin{array}{c}\text { (4) SGR } \\
09-12\end{array}$ & 0.025 & -0.135 & -0.105 & 1 & & & & & 1.09 \\
\hline $\begin{array}{l}\text { (5) } \mathrm{ROE} \\
09-12\end{array}$ & $0.316^{* * *}$ & 0.150 & $0.292 * * *$ & 0.013 & 1 & & & & 1.35 \\
\hline $\begin{array}{c}\text { (6) OWN } \\
09-12\end{array}$ & -0.125 & $0.215^{* *}$ & $0.319^{* * *}$ & -0.107 & 0.020 & 1 & & & 1.17 \\
\hline $\begin{array}{l}\text { (7) OCF } \\
09-12\end{array}$ & $0.303^{* * *}$ & $0.164 *$ & 0.066 & 0.146 & $0.390^{* * *}$ & 0.131 & 1 & & 1.53 \\
\hline $\begin{array}{l}\text { (8) LEV } \\
09-12\end{array}$ & $-0.521^{* * *}$ & 0.078 & $0.446^{* * *}$ & -0.011 & -0.087 & 0.029 & $-0.388^{* * *}$ & 1 & 1.77 \\
\hline
\end{tabular}

None of the correlations among the variables shown in Table 5 exceeds 0.7, and the variance inflation factor (VIF) values are all less than 10; therefore, multicollinearity does not affect the results.

Table 6 shows the correlation between the mean values of the main variables for 2013-2018. Contrary to our prediction, a significantly negative relationship appears between the CSR score and corporate value (TQ) for 2013-2018, as it does for 2009-2012. Looking at the correlation between corporate value (TQ) and other variables, company size (SIZE) shows a negative relationship with corporate value (TQ), as it does for 2009-2012. In addition, return on equity (ROE) and debt-to-equity ratio (LEV) has the same relationship with corporate value (TQ) for 2009-2012. Just as we predicted, the top 10 shareholders' equity $(\mathrm{OWN})$ shows a significantly negative relationship with corporate value (TQ). Lastly, the sales growth rate (SGR) and operating cash flow (OCF) are not statistically related to corporate value (TQ).

Table 6. Pearson correlation for 2013-2018.

\begin{tabular}{|c|c|c|c|c|c|c|c|c|c|}
\hline & (1) & (2) & (3) & (4) & (5) & (6) & (7) & (8) & VIF \\
\hline $\begin{array}{c}\text { (1) TQ } \\
13-18\end{array}$ & 1 & & & & & & & & - \\
\hline $\begin{array}{l}\text { (2) CSR } \\
13-18\end{array}$ & $-0.162 *$ & 1 & & & & & & & 1.87 \\
\hline $\begin{array}{l}\text { (3) SIZE } \\
13-18\end{array}$ & $-0.595^{* * *}$ & $0.632^{* * *}$ & 1 & & & & & & 2.85 \\
\hline $\begin{array}{l}\text { (4) SGR } \\
13-18\end{array}$ & 0.094 & -0.060 & 0.063 & 1 & & & & & 1.12 \\
\hline $\begin{array}{l}\text { (5) ROE } \\
13-18\end{array}$ & $0.182 *$ & $0.194^{* *}$ & 0.142 & 0.064 & 1 & & & & 1.41 \\
\hline $\begin{array}{l}\text { (6) OWN } \\
13-18\end{array}$ & $-0.159 *$ & $0.246^{* * *}$ & $0.324^{* * *}$ & -0.021 & $0.206^{* *}$ & 1 & & & 1.20 \\
\hline $\begin{array}{c}\text { (7) OCF } \\
13-18\end{array}$ & 0.148 & $0.169^{*}$ & 0.091 & $-0.199 * *$ & $0.403^{* * *}$ & $0.260^{* * *}$ & 1 & & 1.39 \\
\hline $\begin{array}{l}\text { (8) LEV } \\
13-18\end{array}$ & $-0.594 * * *$ & 0.109 & $0.512 * * *$ & $-0.200 * *$ & $-0.292 * * *$ & 0.043 & $0.294^{* * *}$ & 1 & 2 \\
\hline
\end{tabular}


Moreover, none of the correlations exceeds 0.7 , and none of the VIF values exceeds 3 ; therefore, multicollinearity is not an issue.

However, this is just a simple correlation analysis. Testing the effect of CSR on corporate value requires a multiple regression analysis that controls for other variables affecting corporate value.

\subsection{Multiple Regression Analysis}

Table 7 shows the regression results for H1. The average value of the CSR score between 2009 and 2012 implies that CSR activities have a negative but insignificant relationship with corporate value. The correlation matrix (see Table 5) also shows the same. These results confirm our prediction that, from 2009 to 2012, corporate costs were high for CSR activities, and social responsibility was slow to convert into economic effects.

Table 7. Effect of CSR on corporate value for 2009-2012.

\begin{tabular}{|c|c|c|c|c|c|c|c|}
\hline \multirow{2}{*}{$\begin{array}{l}\text { TQ 09-12 } \\
\text { Constant }\end{array}$} & \multirow{2}{*}{$\begin{array}{c}\text { Coefficient } \\
7.279\end{array}$} & \multirow{2}{*}{$\begin{array}{c}\text { Standard Error } \\
1.335\end{array}$} & \multirow{2}{*}{$\frac{\text { t-Value }}{5.451}$} & \multirow{2}{*}{$\frac{p \text {-Value }}{0.000}$} & \multicolumn{2}{|c|}{ 95\% Confidence Interval } & \multirow[b]{2}{*}{$* * *$} \\
\hline & & & & & 4.631 & 9.928 & \\
\hline CSR 09-12 & -0.003 & 0.007 & -0.495 & 0.622 & -0.016 & 0.010 & \\
\hline SIZE 09-12 & -0.228 & 0.072 & -3.164 & 0.002 & -0.370 & -0.085 & $* *$ \\
\hline SGR 09-12 & -0.012 & 0.031 & -0.382 & 0.703 & -0.073 & 0.050 & \\
\hline ROE 09-12 & 4.632 & 1.037 & 4.468 & 0.000 & 2.576 & 6.688 & $* * *$ \\
\hline OWN 09-12 & -0.000 & 0.004 & -0.101 & 0.919 & -0.009 & 0.008 & \\
\hline OCF 09-12 & 1.457 & 1.544 & 0.944 & 0.348 & -1.605 & 4.519 & \\
\hline LEV 09-12 & -1.390 & 0.474 & -0.283 & 0.004 & -2.330 & -0.449 & $* *$ \\
\hline \multicolumn{2}{|c|}{ Adj_R Square } & \multicolumn{2}{|c|}{0.423} & \multicolumn{2}{|c|}{ Sample size } & \multicolumn{2}{|l|}{111} \\
\hline \multicolumn{2}{|c|}{ F-statistics } & \multicolumn{2}{|c|}{$12.536^{* * *}$} & \multicolumn{2}{|c|}{ Durbin-Watson } & \multicolumn{2}{|l|}{2.256} \\
\hline
\end{tabular}

Notes: ${ }^{* * *}$ and ${ }^{* *}$ indicate significance at the $1 \%, 5 \%$, and $10 \%$ levels, respectively.

Table 8 shows the regression results for H2. The average value of the CSR score for 2013-2018 implies that CSR activities have a positive and significant relationship with corporate value. This result is contrary to that for 2009-2012 because the Chinese government placed more emphasis on CSR activities after 2013, and investments were made to encourage companies to implement CSR activities and help the firms improve their corporate value through them.

Table 8. Effect of CSR on corporate value for 2013-2018.

\begin{tabular}{|c|c|c|c|c|c|c|c|}
\hline TQ 13-18 & Coefficient & Standard Error & t-Value & $p$-Value & \multicolumn{2}{|c|}{$95 \%$ Confidence Interval } & \\
\hline Constant & 10.131 & 1.240 & 8.171 & 0.000 & 7.672 & 12.590 & $* * *$ \\
\hline CSR 13-18 & 0.016 & 0.006 & 2.588 & 0.011 & 0.004 & 0.029 & $* *$ \\
\hline SIZE 13-18 & -0.368 & 0.066 & -5.533 & 0.000 & -0.499 & -0.236 & $* * *$ \\
\hline SGR 13-18 & 0.012 & 0.108 & 0.108 & 0.914 & -0.202 & 0.225 & \\
\hline ROE 13-18 & 1.097 & 0.615 & 1.785 & 0.077 & -0.122 & 2.136 & $*$ \\
\hline OWN 13-18 & -0.003 & 0.004 & -0.589 & 0.557 & -0.011 & 0.006 & \\
\hline OCF $13-18$ & 0.847 & 1.373 & 0.617 & 0.539 & -1.876 & 3.569 & \\
\hline LEV 13-18 & -1.095 & 0.445 & -2.459 & 0.016 & -1.978 & -0.212 & $* *$ \\
\hline \multicolumn{2}{|c|}{ Adj_R Square } & \multicolumn{2}{|c|}{0.488} & \multicolumn{2}{|c|}{ Sample size } & \multicolumn{2}{|l|}{111} \\
\hline \multicolumn{2}{|c|}{ F-statistics } & \multicolumn{2}{|c|}{$15.986^{* * *}$} & \multicolumn{2}{|c|}{ Durbin-Watson } & \multicolumn{2}{|l|}{1.919} \\
\hline
\end{tabular}

Finally, each regression formula for 2009-2012 and 2013-2018 is shown in the following:

TQ09-12 $=7.279-0.003 \mathrm{CSR}-0.228 \mathrm{SIZE}-0.012 \mathrm{SGR}+4.632 \mathrm{ROE}-0.000 \mathrm{OWN}+1.457 \mathrm{OCF}-$ 1.390LEV

TQ13-18 $=10.131+0.016 \mathrm{CSR}-0.368 \mathrm{SIZE}+0.012 \mathrm{SGR}+1.097 \mathrm{ROE}-0.003 \mathrm{OWN}+0.847 \mathrm{OCF}-$ 1.095LEV

Overall, the coefficient of CSR for 2009-2012 is -0.003, and that for 2013-2018 is 0.016. This implies that the impact of CSR activities on corporate value from 2013 to 2018 in China is greater than that from 2009 to 2012. These results support H3. 


\subsection{Robustness Test: Alternative Measure of Company Value}

We ensure the robustness of our results using an alternative measure of corporate value, substituting Tobin's Q with MV (market value). The results using the alternative measure are reported for 2009-2012 and 2013-2018 separately in Tables 9 and 10. The coefficient of CSR for 2009-2012 remains insignificant $(p=0.895)$, and the coefficient of CSR for 2013-2018 also remains positively significant $(p=0.002)$. These results are consistent with those wherein corporate value is measured by Tobin's $Q$.

Table 9. Robustness checks: alternative measure of corporate value for 2009-2012.

\begin{tabular}{|c|c|c|c|c|c|c|c|}
\hline \multirow{2}{*}{$\begin{array}{c}\text { MV 09-12 } \\
\text { Constant }\end{array}$} & \multirow{2}{*}{$\begin{array}{c}\text { Coefficient } \\
3.734\end{array}$} & \multirow{2}{*}{$\begin{array}{c}\text { Standard Error } \\
0.510\end{array}$} & \multirow{2}{*}{$\begin{array}{c}\text { t-Value } \\
7.318\end{array}$} & \multirow{2}{*}{$\frac{p \text {-Value }}{0.000}$} & \multicolumn{2}{|c|}{ 95\% Confidence Interval } & \multirow[b]{2}{*}{$* * *$} \\
\hline & & & & & 2.722 & 4.746 & \\
\hline CSR 09-12 & 0.000 & 0.003 & 0.132 & 0.895 & -0.005 & 0.005 & \\
\hline SIZE 09-12 & 0.860 & 0.027 & 31.283 & 0.000 & 0.806 & 0.915 & $* * *$ \\
\hline SGR 09-12 & -0.001 & 0.012 & -0.044 & 0.965 & -0.024 & 0.023 & \\
\hline ROE 09-12 & 2.201 & 0.396 & 5.556 & 0.000 & 1.415 & 2.986 & $* * *$ \\
\hline OWN 09-12 & 0.000 & 0.002 & 0.169 & 0.866 & -0.003 & 0.004 & \\
\hline OCF 09-12 & 0.097 & 0.590 & 0.165 & 0.869 & -1.073 & 1.267 & \\
\hline LEV 09-12 & -0.614 & 0.181 & -3.388 & 0.001 & -0.973 & -0.255 & $* * *$ \\
\hline \multicolumn{2}{|c|}{ Adj_R Square } & \multicolumn{2}{|c|}{0.961} & \multicolumn{2}{|c|}{ Sample size } & \multicolumn{2}{|c|}{111} \\
\hline \multicolumn{2}{|c|}{ F-statistics } & \multicolumn{2}{|c|}{$390.241 * * *$} & \multicolumn{2}{|c|}{ Durbin-Watson } & \multicolumn{2}{|c|}{1.779} \\
\hline
\end{tabular}

Table 10. Robustness checks: alternative measure of corporate value for 2013-2018.

\begin{tabular}{|c|c|c|c|c|c|c|c|}
\hline \multirow{2}{*}{$\begin{array}{l}\text { TQ 13-18 } \\
\text { Constant }\end{array}$} & \multirow{2}{*}{$\begin{array}{c}\text { Coefficient } \\
4.790\end{array}$} & \multirow{2}{*}{$\begin{array}{c}\text { Standard Error } \\
0.482\end{array}$} & \multirow{2}{*}{$\begin{array}{c}\text { t-Value } \\
9.936\end{array}$} & \multirow{2}{*}{$\begin{array}{c}p \text {-Value } \\
0.000\end{array}$} & \multicolumn{2}{|c|}{ 95\% Confidence Interval } & \multirow[b]{2}{*}{$* * *$} \\
\hline & & & & & 3.834 & 5.747 & \\
\hline CSR 13-18 & 0.008 & 0.002 & 3.189 & 0.002 & 0.003 & 0.013 & $* *$ \\
\hline SIZE 13-18 & 0.808 & 0.026 & 31.263 & 0.000 & 0.756 & 0.859 & $* * *$ \\
\hline SGR 13-18 & 0.001 & 0.042 & 0.012 & 0.990 & -0.082 & 0.083 & \\
\hline ROE 13-18 & 0.690 & 0.239 & 2.885 & 0.005 & 0.215 & 1.164 & $* *$ \\
\hline OWN 13-18 & -0.002 & 0.002 & -0.991 & 0.324 & -0.005 & 0.002 & \\
\hline OCF 13-18 & 0.376 & 0.534 & 0.704 & 0.483 & -0.683 & 1.435 & \\
\hline LEV 13-18 & -0.431 & 0.173 & -2.488 & 0.014 & -0.774 & -0.087 & $* *$ \\
\hline \multicolumn{2}{|c|}{ Adj_R Square } & \multicolumn{2}{|c|}{0.964} & \multicolumn{2}{|c|}{ Sample size } & \multicolumn{2}{|c|}{111} \\
\hline \multicolumn{2}{|c|}{ F-statistics } & \multicolumn{2}{|c|}{$423.322 * * *$} & \multicolumn{2}{|c|}{ Durbin-Watson } & \multicolumn{2}{|c|}{1.611} \\
\hline
\end{tabular}

Notes: ${ }^{* *}$ and ${ }^{* *}$ indicate significance at the $1 \%, 5 \%$, and $10 \%$ levels, respectively.

\section{Conclusions}

Nowadays, CSR is widely given importance in the international community. CSR is not only the demand of the enterprise's own development, but also the demand of national strategy and government governance of social issues. In the last decade in China, the views of governments, public and companies on CSR have all changed. This research is devoted to studying the changes in the relationship between CSR and corporate value using a sample of companies listed in the Chinese market from 2009 to 2018. The results are as follows. First, this study confirms that there is no statistical correlation between CSR activities and corporate value from 2009 to 2012. This implies that in this stage, the conduct of CSR activities had no influence on corporate value for companies. Second, we found that CSR activities had a positive effect on corporate value from 2013 to 2018. Third, our results show that the impact of CSR activities on corporate value has become much stronger over time. These results suggest that the conduct of CSR activities in China increased corporate value in the period from 2013 to 2018, supporting the results of most recent studies, and the influence is getting stronger and stronger.

CSR in Chinese traditional culture refers to righteousness. Confucius said that wealth and nobility are what people want, and if you do not get it by the way, you will not get anywhere [62]. We can know that righteousness was more important than profit in ancient times. Since the establishment of modern society, China has neglected corporate social responsibility in order to develop the economy, which has led to a series of problems. In order to solve these problems, all parties in China began to attach importance to corporate social responsibility. In the period of 2009-2012 CSR was developing 
rapidly, and its importance and necessity were being grasped in China. However, the investment costs of CSR activities were very high in this economic environment, and the government also had little input in encouraging companies to engage in social responsibility at this stage. In addition, it takes time for CSR activities to convert into economic benefits. This is likely why CSR is not correlated with corporate value at this stage. During the stage of 2013-2018, CSR activities in China were standardized and became more normative. In addition, the Chinese government emphasized CSR activities and implemented many policies to promote them during this period. Finally, CSR activities were converting into economic benefits more quickly because media reports on CSR activities were increasing, and the public could easily read them on the Internet. Therefore, CSR activities were having a positive effect on corporate value in the short term.

At present, most of the existing studies focus on the relationship between CSR and corporate value. Several studies on the impact of CSR activities on corporate value have shown both negative and positive correlations, as well as no correlation, with corporate value. Other studies have shown a negative relationship between CSR activities and corporate value in the current year and a positive relationship in the next year. Nevertheless, it makes it interesting to see the change of the relationship between them. Furthermore, unlike most of the previous studies which used a maximums of three years of data, we expanded the range to 10 years of data. Hence, we provide a new perspective on the relationship between CSR and corporate value.

Based on this study, corporations should realise that in the current environment, the conduct of CSR activities and the maximization of enterprise value are not two opposite things. Corporations' conduct of CSR activities will not reduce corporate value but increase corporate value. Especially in today's globalized world, the Chinese companies which want to go abroad can, through conduct of CSR activities, enhance their global competitiveness, and also have a reference of significance for these foreign companies which want to enter the Chinese market, or want to conduct transactions with Chinese companies to create company development strategy.

Our study has several limitations. First, the values of our variables are averages, making it impossible to determine the year in which the impact of CSR activities on corporate value changes. Second, we studied changes in the relationship between CSR activities and corporate values only in the current period; changes in the impact of CSR activities on corporate value in the next year and the next two years should also be studied. Third, restricting the sample to companies for which all necessary financial information is available from 2009 to 2018 may have led to sample selection bias. Future studies should seek to overcome these limitations and extend this line of research.

Author Contributions: Conceptualization, F.Z. and J.-y.J.; methodology, F.Z.; validation, F.Z. and J.-y.J.; formal analysis, F.Z.; investigation, J.-y.J.; resources, F.Z.; data curation, F.Z.; writing-original draft preparation, F.Z.; writing-review and editing, J.-y.J.; supervision, J.-y.J. and F.Z. All authors have read and agreed to the published version of the manuscript.

Funding: This research received no external funding.

Acknowledgments: We appreciate support from Inha University.

Conflicts of Interest: The authors declare no conflict of interest.

\section{References}

1. Zhang, D.Y.; Morse, S.; Ma, Q.Y. Corporate social responsibility and sustainable development in China: Current status and future perspectives. Sustainability. 2019, 11, 4392. [CrossRef]

2. Park, J.H.; Park, H.Y.; Lee, H.Y. The effect of social ties between outside and inside directors on the association between corporate social responsibility and firm value. Sustainability 2018, 10, 3840. [CrossRef]

3. Elif, A.S. Corporate social responsibility and financial performance: The moderating role of ownership concentration in Turkey. Sustainability 2019, 11, 3643.

4. Liu, N.N.; Liu, C.Z.; Guo, Q.; Da, B.; Guan, L.N.; Chen, H.Y. Corporate social responsibility and financial performance: A quantile regression approach. Sustainability 2019, 11, 3717. [CrossRef] 
5. Sial, M.S.; Zheng, C.M.; Khuong, N.V.; Khan, T.; Usman, M. Does firm performance influence corporate social responsibility reporting of Chinese listed companies? Sustainability 2018, 10, 2217. [CrossRef]

6. Yang, M.H.; Bento, P.; Akbar, A. Does CSR influence firm performance indicators? Evidence from Chinese pharmaceutical enterprises. Sustainability 2019, 11, 5656. [CrossRef]

7. Sampong, F.; Song, N.; Boahene, K.O.; Wadie, K.A. Disclosure of CSR performance and firm value: New evidence from south Africa on the basis of the GRI Guidelines for sustainability disclosure. Sustainability 2018, 10, 4518. [CrossRef]

8. Li, K.; Khalili, N.R.; Cheng, W.Q. Corporate social responsibility practices in China: Trends, context, and impact on company performance. Sustainability 2019, 11, 354. [CrossRef]

9. Freeman, R.; Liedtka, J. Corporate social responsibility: A critical approach. Bus. Horizons 1991, 34, 92-98. [CrossRef]

10. Cornell, B.; Shapiro, A.C. Corporate Stakeholders and Corporate Finance. Financial Manag. 1987, 16. [CrossRef]

11. Zeng, T. Corporate social responsibility, tax aggressiveness, and firm value. Account. Perspect. 2016, 15, 455-462. [CrossRef]

12. Li, S. The evolution of corporate social responsibility theory and literature review. North. Econ. 2007, 11, 46-49. (In Chinese)

13. Zhu, Y.Q. An empirical study of corporate social responsibility and corporate value. Res. Financ. Econ. Issues 2010, 2, 102-106. (In Chinese)

14. Kong, Y.S.; Li, J. Research on the correlation between corporate social responsibility and financial performance: Taking Shanghai A-share manufacturing industry as an example. Financ. Account. Mon. 2010, 5, 14-17. (In Chinese)

15. Yang, H.X. Research on the correlation between corporate social and financial performance based on multiple regression model. Fri. Account. 2014, 5, 105-108. (In Chinese)

16. Yu, X.H.; Wu, W.J. Corporate governance, corporate social responsibility and corporate value. Res. Cont. Econ. Res. 2014, 5, 74-78. (In Chinese)

17. Yun, F. Research on the Correlation between Social Responsibility and Corporate Value of My Country's Electric Power Listed Companies; North China Electric Power University: Beijing, China, 2016.

18. Ji, C.L.; Yang, P. Research on the correlation between the corporate social responsibility and corporate value of E-commerce platform companies-Based on the Empirical Analysis of Alibaba, JD and Jumei Youpin. Econ. Manag. 2016, 30, 89-96. (In Chinese)

19. Sun, M.; Zhang, Y. Corporate governance, corporate social responsibility and corporate value. Friends Account. 2012, 10, 100-103. (In Chinese)

20. Wang, Y.L. Research on the Correlation between Corporate Social Responsibility and Financial Performance from the Perspective of Ownership Structure; Qingdao University: Qingdao, China, 2015. (In Chinese)

21. Jiang, H.C. Corporate Social Responsibility, Ownership Structure and Corporate Value; Yangzhou University: Yangzhou, China, 2019. (In Chinese)

22. Seo, W.; Park, M.Y. Corporate social responsibility and firm value in China. Financ. Account. Inf. J. 2015, 15, 103-125. (In Korean)

23. Dai, M.; Kang, H.J. The effect of corporate social responsibility on firm value to Chinese companies. J. Korea Cont. Assoc. 2013, 12, 422-427. (In Korean) [CrossRef]

24. Shin, M.S.; Kim, S.U.; Kim, B.S. The impact of corporate social responsibility spending on corporate value. Financ. Eng. Res. 2011, 10, 99-125. (In Korean)

25. Jeon, I.; Seol, Y.M.; Kim, C.K. The relationship between corporate social responsibility and corporate value. Manag. Res. 2012, 27, 361-387. (In Korean)

26. Jin, L.; Yang, D.H.; Hong, Y.D.; Choi, J.H. International comparison of the relationship between corporate social responsibility and firm value: Korea and China. Korean Account. 2016, 25, 67-112. (In Korean)

27. David, P.; Kline, S.; Dai, Y. Corporate Social Responsibility Practices, Corporate Identity, and Purchase Intention: A Dual-Process Model. J. Public Relations Res. 2005, 17, 291-313. [CrossRef]

28. Waddock, S.A.; Graves, S.B. The corporate social performance-financial performance link. Strateg. Manag. J. 1997, 18, 303-319. [CrossRef]

29. Deng, D.M. Analysis of the relationship between corporate social responsibility and corporate performance. Sci. Tech. Entr. Mon. 2005, 18, 116-117. (In Chinese) 
30. Li, S.C.; Zhang, C.W.; Li, F. Research on the relationship between social responsibility and financial performance of electric power companies-based on panel data of 51 companies from 2011 to 2013. Friends Account. 2015, 24, 60-64. (In Chinese)

31. Zhang, W.B. An Empirical Study on the Relationship between Corporate Social Responsibility and Financial Performanc; Soochow University: Suzhou, China, 2010. (In Chinese)

32. Yin, K.G.; Liu, X.Q. Research on the relationship between corporate social responsibility and financial performance based on endogeneity-empirical evidence from Chinese listed companies. China Soft Sci. 2014, 29, 98-107. (In Chinese)

33. Ko, S.C.; Park, R.S. Determinants of corporate social responsibility and corporate value. Tax. Account. J. 2011, 12, 105-134. (In Korean)

34. Kim, C.S. Corporate social responsibility and corporate value. Korea Sec. Sch. J. 2009, 38, 507-545. (In Korean)

35. Vance, S.C. Are socially responsible corporations good investment risk? Manag. Rev. 1975, 64, 18-24.

36. Friedman, M. The social responsibility of business is to increase its profits. N. Y. Tim. Mag. 1970, 13, 32-33.

37. Aupperle, K.E.; Carroll, A.B.; Hatfield, J.D. An empirical examination of the relationship between corporate social responsibility and profitability. Acad. Manag. J. 1985, 28, 446-463.

38. Li, Z. Research on the correlation between corporate social responsibility and corporate value: Empirical evidence from listed companies on the Shanghai Stock Exchange. Chin. Ind. Econ. 2016, 2, 77-83. (In Chinese)

39. Makni, R.; Francoeur, C.; Bellavance, F. Causality between corporate social performance and financial performance: From Canadian firms. J. Bus. Ethics 2009, 3, 409-422. [CrossRef]

40. Yang, W.S.; Yang, S.L. An empirical study on the relationship between corporate social responsibility and financial performance in the Chinese context-Based on the comparative analysis of large, medium and small listed companies. China Manag. Sci. 2016, 24, 143-150. (In Chinese)

41. Brammer, S.; Brooks, C.; Pavelin, S. Corporate social performance and stock returns: UK evidence from disaggregate measures. Financ. Manag. 2006, 35, 97-116. [CrossRef]

42. Shane, P.B.; Spicer, B.H. Market response to environmental information produced outside the firm. Account. Rev. 1983, 58, 521-538.

43. Wright, P.; Ferris, S.P. Agency conflict and corporate strategy: The effect of divestment on corporate value. Strateg. Manag. J. 1997, 18, 77-83. [CrossRef]

44. Pan, F.; Wang, L. Research on the relationship between corporate environmental investment and economic performance. New Account. 2015, 4, 6-11. (In Chinese)

45. Chen, K.; Li, S.T. The impact of corporate social responsibility on financial performance: A key element perspective. Stat. Res. 2010, 27, 105-111. (In Chinese)

46. Ullman, A. Data in search of a theory: A critical examination of the relationship among social performance, social disclosure, and economic performance. Acad. Manag. Rev. 1985, 10, 540-577.

47. Bauer, R.; Koedijk, K.; Otten, R. International evidence on ethical mutual fund performance and investment style. J. Bank. Financ. 2005, 29, 1751-1767. [CrossRef]

48. Wen, S.B.; Fang, Y. An empirical study on the relationship between corporate social responsibility and financial performance-Panel data analysis from the perspective of stakeholders. Chin. Ind. Econ. 2008, 10, 150-160. (In Chinese)

49. Tu, H.; Zheng, H. Corporate social responsibility, ownership and company value. Nankai J. 2018, 6, 147-156. (In Chinese)

50. Derwall, J.; Guenster, N.; Bauer, R.; Koedijk, K. The eco-efficiency premium puzzle. Financ. Anal. J. 2005, 61, 51-63. [CrossRef]

51. Liu, L.J.; Chen, X.M. Research on the impact of corporate responsibility on financial performance. Stat. Dec. 2010, 14, 149-151. (In Chinese)

52. Zhang, Z.G.; Jin, X.C.; Li, G.Q. An empirical study on the intertemporal impact of corporate social responsibility and financial performance. Account. Res. 2013, 8, 32-39. (In Chinese)

53. Wang, N. The Study on the Relationship between Social Responsibility Fulfillment and Firm Value in Private Enterprises-A Case Study of Chengzhang Group; Xi'an University: Xi'an, China, 2018. (In Chinese)

54. Wu, Y. Property Rights, Corporate Social Responsibility and Enterprise Value-Taking Agricultural Listed Companies as an Example; Wuhan Polytechnic University: Wuhan, China, 2018. (In Chinese)

55. Sheldon, O. The Philosophy of Management; Sir Isaac Pitman and Sons Ltd.: London, UK, 1924. 
56. Schnepp, G.J.; Bowen, H.R. Social Responsibilities of the Businessman. Am. Cathol. Sociol. Rev. 1954, 15, 42. [CrossRef]

57. Carroll, A. A three-dimensional conceptual model of corporate social performance. Acad. Manag. Rev. 1979, 4, 497-505. [CrossRef]

58. Yin, Q. On the impact of CSR on the sustainable development of enterprises based on John Elkingtor's “Triple Bottom Line' theory. Oriental Enterprise Culture. 2012, 7, 203-204. (In Chinese)

59. Li, H.Y.; He, B.; Chen, H.; Wu, J.Q. My country's CSR large sample empirical research: Theory, method and data processing. Financ. Account. Mon. 2019, 15, 122-132. (In Chinese)

60. Xi, J.P. Zhi jiang xin yu. Zhejiang Dly. 2007, 251. Available online: https://books.google.com.hk/books/about/ $\% \mathrm{E} 4 \% \mathrm{~B} 9 \% 8 \mathrm{~B} \% \mathrm{E} 6 \% \mathrm{B1} \% 9 \mathrm{~F} \% \mathrm{E} 6 \% 96 \% \mathrm{~B} 0 \% \mathrm{E} 8 \% \mathrm{AF} \% \mathrm{AD} \cdot \mathrm{html}$ ?id=4jrgDwAAQBAJ\&printsec=frontcover\& source=kp_read_button\&redir_esc=y\#v=onepage\&q\&f=false (accessed on 2 November 2020). (In Chinese).

61. Zhou, X.M. Corporate Social Responsibility and Stake Holder Value Maximization -Based on the Perspective of Mergers and Acquistions; Jilin University: Jilin, China, 2018. (In Chinese)

62. Ogasawara, K. Analects of Confucius. Jpn. J. Radiol. Technol. 2011, 67, 67. (In Chinese) [CrossRef]

Publisher's Note: MDPI stays neutral with regard to jurisdictional claims in published maps and institutional affiliations.

(C) 2020 by the authors. Licensee MDPI, Basel, Switzerland. This article is an open access article distributed under the terms and conditions of the Creative Commons Attribution (CC BY) license (http://creativecommons.org/licenses/by/4.0/). 